\title{
Role of Language in Shaping Cultural Identity
}

\author{
Babita Parajuli \\ Pokhariya Secondary School, Biratnagar-3 Morang \\ M. Phil Scholar, Nepal Open University
}

\begin{abstract}
This paper aims to explore the role of language in shaping the cultural identity of people in a society with an argumentative explanation based on the relevant literature. The descriptive summary from the documentary analysis in the paper mainly focuses on the positive and communicational role of language to establish the foundation of cultural landscape through the continuous representation and transmission of diverse cultural characteristics such as people's thoughts, behaviors, cultural histories, traditions, values, principles and boundaries within a socio-cultural context. Moreover, the paper indicates that language as a linguistic channel navigates people's commonality and unity framing them in a single pattern of cultural identity. It is suggested that every language as a powerful source of introducing cultural politics requires continuous transmission, preservation and promotion by the nation as an opportunity for the new generations to be born with distinct cultural identity.
\end{abstract}

Keywords: cultural identity, language learning, cultural representation, language hegemony, ancestral dialects

\section{CONTEXT}

Language is one of the determiners of understanding people's culture in the world. When a speaker communicates a particular language people may speculate about the origin, nationality, culture, religion and ethnicity of the speaker as language reflects embedded cultural identities of people within a language. Hall (1997) states that language represents the shared meanings of a particular culture and culture exchanges the meaning through language with the society members.

Primarily, language as one of the mediums of conveying innumerable opinions, ideas, emotions and knowledge serves multiple functions in framing the diverse cultural identities of a particular group. Different languages representing diverse geographical locations express people's voices reflecting their cultural identities. The language and culture continuously co-create cultural values, traditions and identities through human interaction (Maine et al., 2019). Language can reveal the different hidden social and cultural realities of the people when they develop a certain lifestyle and culture with the family members and society through languages from early life. Bucholtz and Hall (2005) state that a person's identity results in linguistic interaction as a social and cultural phenomenon rather than an internal and psychological one. Therefore, the linguistic performance of individuals distinguishes their cultural identity as they use distinct language to talk and perceive the world. 
Many social theorists and cultural researchers in the area of sociolinguistics and anthropology argue for the role of language in shaping cultural identity. For example, Kennedy (2019) states that language can positively navigate and construct cultural identity by strengthening the connection of people in the community. Similarly, Ennaji (2005) illustrates that what factor differentiates an Arab and a French from an Igbo has the cultural communicative function of their mother tongue as the culture can transmit the people's shared mentality, lifestyle and behaviors based on local, tribal and national languages. Every language with a distinctive nature shapes the people's cultural identity with the reflection of different social and cultural realities, historical traditions, typical lifestyles, shared cultural values and belief systems of a specific society resulting in the promotion of solidarity, preservation of cultural traditions and developing the socio-cultural system of a nation.

The main purpose of this paper is to explore the question of how the role of language is in shaping the cultural identity of people in society providing an argumentative description based on the relevant literature. The related themes are presented in the following sections to analyze and explain the role of language in shaping cultural identity.

\section{Language and Cultural Identity}

Language is the tool of cultural sharing between the members of a community because interacting in a language means understanding the culture and the process of being an integral part of it.

Supporting this, Fuller (2007) emphasized that the cultural identity depended on interlocutors 'interactions and the choice of language in different social contexts. Similarly, Vygotsky (1980) argued that the interaction between individuals and the community performed the semiotic functions therefore language as a linguistic and cognitive tool supported children to internalize the social and cultural thoughts of others at first before framing their psychological thoughts in the community. However, some researchers questioned the role of language as a sole source of framing the cultural identity by stating that language also can create a cultural identity crisis in the society as Giri (2010) stressed that people speaking Nepali and English languages had more power and control over the minority language speakers in Nepal leading socio-cultural and linguistic disorders and identity crisis with socio-economical displacement.

This may be the case that language can create a cultural identity crisis as a threat however Edewor et al. (2014) claimed that cultural identity could be redefined and restructured to address the crisis and the denial of identity, security, equality and autocratic roles of the government was more responsible to create ethnic or cultural conflict in Nigeria. Similarly, language acquisition and the foundation of cultural identity take place earlier than the situation of an identity crisis (Gelman \& Roberts, 2017).

The above findings of the literature show that language guides the cultural identity as language comes first before learning about the culture and framing identity in a new social situation. 


\section{Language Transmission and Cultural Exchange}

Language transmission from one generation to another generation provides a foundation for cultural transmission and modification as mother tongue interaction in a family and society helps to learn all the basic cultural values and traditions which grow as an identity in the future.

Gelman and Roberts (2017) indicated that language as a powerful engine of cultural transmission exchanged different sets of cultural skills representing the private, public, cultural and mental system of the society. Likewise, Kinzler et al. (2011) interpreted the role of mother tongue as one of the social and cultural identity markers as more than 6000 mutually unintelligible human languages were mostly learnable in early childhood. However, some researchers argue that language transmission within a particular culture can be challenging for establishing a separate cultural identity if the language speakers migrated from one nation or culture to the next as Bhugra (2004) contradicted that when individuals from a particular sociocultural background migrated to another linguistic and cultural background, they might feel socio-economically disadvantaged, culturally discriminated and alienated.

Learning language and shaping a new cultural identity can be a problem for people in the new socio-cultural context, on the contrary, the findings of Miller and Collette (2019) emphasized that people improved their multicultural identity and life standard developing the required skills to function in the multicultural society after learning the international languages with a sense of satisfaction in the target culture and the pride of one's culture at the same time.

Therefore, these findings present that learning and transmission of language continuously exchange cultural and multicultural identities irrespective of geographical location.

\section{Language Hegemony and Cultural Representation}

Multiple ethnic minority languages in Nepal have not been officially promoted and preserved from the national level as a result cultural traditions and identity embedded within these languages are on the verge of extinction. As the majority of people use the Nepali language in the written and spoken discourse and English and Nepali languages are widely practiced as the medium of education, media, technology, business and economics. Supporting this, Phyak (2013) identified that many local languages of indigenous communities had fragile socio-political, economic and educational representation due to the monolingual language policies of the country therefore the language policies needed to establish the ethnic and cultural identity of indigenous people incorporating them in the explicit policy formation and implementation. Similarly, Giri (2011) argued that Nepal as a linguistically and culturally diversified country was ignorant to promote ethnic minority languages due to the invisible language politics by the interest of ruling elites as a result minority language had no definable position and adequate recognition in different fields and language policy.

Focusing the representation of minority languages in media, Amatya (2015) reported that about $6.58 \%$ of indigenous media and journalists have empowered their languages and culture 
by informing and entertaining indigenous people since there were 43 Newari, 13 Tharu, and 10 Tamang and two Rai languages newspapers including Gorkhaparta supplement daily from 32 indigenous languages.

On the other hand, Baral (2020) reported that the Danuwar community of Sindhuli district as one of the $63^{\text {rd }}$ marginalized communities of Nepal was not in the media access to receive the information about COVID-19 and the majority of them did not understand the Nepali language information broadcasting from the local radios and television since they had own cultural identity speaking Done as mother tongue.

These findings indicate that promoting a language preserves the cultural and ethnic identity, where there is the matter of one language hegemony over others, direct influence on the cultural identity is observed which connects language to shape the cultural identity.

\section{Preservation of Language as a Cultural Pride}

Language develops and preserves the culture and culture interacts within the language system therefore people with different castes and communities persistently want to preserve their languages and cultural identity as cultural pride. For example, Gurung (2019) reported that the Gurung community of Nepal wanted to develop a unified language script to preserve and promote their cultural and ethnic identity for future generations as they were anxious that many Gurungs lived in the foreign country without practicing their spoken and written language and many youths in Nepal also started learning Korean and Japanese language to go abroad for the job. Similarly, Katuwal (2018) reported that Khas is a major source of modern Nepali language spoken by Chhetris, Bahuns, Thakuris and Dalits communities in the Karnali province of Nepal including many indigenous languages such as Surel, Sanskrit, Hayu, Pahari, Meche, Jirel, Dhimal and Kumal needed promotion and attention which were in the verge of extinction due to the rare speakers for preserving the cultural interactions in these ancestral dialects.

Some scholars argue that cultural identity is more than only language preservation, as various aspects can replicate the cultures. For example, Chapagain (2018) reported that the Raute tribe of Nepal represented their separate cultural identity in terms of their dresses, lifestyles and traditional belief system that they perceived the world differently and loved their migrating nature thinking of the sky as their blanket and the earth as their bed.

However, Silwal (2011) asserted the Raute people and their children did not understand the Nepali language as they have been establishing their nomadic lifestyle and cultural identity through the transmission of the Raute language system. Therefore, how cultural identity presents a particular community can be the output of the language system.

These findings reflect that the close connection between language and cultural identity that lack language preservation brings a threat to their cultural identity therefore people with specific cultures want to promote their language system to endorse their ethnic dignity and cultural pride. 


\section{Language Learning and Cultural Identity}

Cultural identity is associated with language learning because recognizing language elements enable learners to assimilate with the cultural activities, sign, symbols and societal consciousness encouraging to adjust in the new culture. Li (2013) argued that cultural understanding and cultural transformation can be increased through learning diverse linguistic features of a language which empowered learners against cultural hegemony. Similarly, Freire (2020) focused that the multicultural and multilingual teaching-learning practices emphasized socio-political consciousness, cultural awareness and social actions to foster the cultural identity of the individual using languages.

However, Pinto and Araújo e Sá (2020) contradicted that language and cultural identity go parallel to overcome the issues in society from diverse perspectives instead of promoting each other. On the contrary, Donitsa-Schmidt and Vadish (2005) highlighted that language proficiency and acculturation enabled the North American students to learn the Hebrew language, Israeli culture and lifestyle for establishing new Israeli cultural identity while studying there.

Therefore, the above literature emphasise that language learning is one of the significant components to trace the cultural identity promoting language learners to assimilate into the new culture. For example, if someone is interested to understand and adopt the Newari culture, they need to learn the Newari language as a foundation for shaping the Newari cultural identity.

\section{CONCLUSION}

The language as a social interactional tool plays a crucial role to shape the cultural identity representing and framing people's linguistic and cultural backgrounds to exchange their personal experiences, social realities, cultural norms and historical traditions among the members of a specific group establishing an enriched socio-cultural life within a country.

The paper illustrates that communicating in a language means understanding and interpreting the in-depth social and cultural standards, values, lifestyle, signs, symbols and directions related to a particular culture to reveal a separate cultural identity. Similarly, culture as a social system nurtures language development in society and largely frames the expressions of human narratives in their family and society. The paper reflects that people with a distinct language and cultural identity feel proud to celebrate their linguistic and cultural solidarity as language establishes the system of representation and transmission of cultures over the generations. Furthermore, the promotion and preservation of languages develop the notion of multiculturalism with the sound socio-political and cultural environment in the country. The recognition of linguistic elements promotes cultural identity as national pride. As presented in the studies, languages upraise the cultural positioning of a community generating development opportunities in different fields such as socio-politics, education, media and economics.

Additionally, language functions as a cognitive tool to express and internalize the linguistic terms relevant to the cultural background therefore the change of linguistic region may 
result in individuals' adaptation to the new culture reframing linguistic diversity with cultural identity. The different features and levels of mother tongue interconnect thoughts, cultural ethics and social happenings in the form of cultural identity in the community. The content analysis of the different themes highlight that a language creates the environment to reflect the culture and culture provides the field to language practice therefore language learning and transmission for cultural representation as a whole characterize the role of language in shaping and maintaining a distinct cultural identity in the changing world. All human beings need to be responsible to save the languages for shaping cultural identity.

Our internal thoughts and emotions may not be always ours, rather communicated and shaped by the lens of our culture

\section{REFERENCES}

Amatya, M. R. (2015, August 2). Voice of the people. The Kathmandu Post. https://kathmandupost.com/opinion/2015/08/02/voice-of-the-people

Baral, S. (2020, 6 July). For marginalised, access to media and information a major challenge during pandemic. The Kathmandu Post, 3.

https://kathmandupost.com/province-no-3/2020/07/06/for-marginalised-access-tomedia-and-information-a-major-challenge-during-pandemic

Bhugra, D. (2004). Migration, distress and cultural identity. British medical bulletin, 69(1), 129141.

Bucholtz, M., \& Hall, K. (2005). Identity and interaction: A sociocultural linguistic approach. Discourse studies, 7(4-5), 585-614. https://doi.org/10.1177/1461445605054407

Chapagain, B. (2018, 15 December). Herne katha [YouTube Video]. https://www.youtube.com/watch?v=DfrlWm-sWDU

Donitsa-Schmidt, S., \& Vadish, M. (2005). American students in Israel: An evaluation of a study abroad experience. Frontiers: The Interdisciplinary Journal of Study Abroad, 11(1), 33-56.

Edewor, P., Aluko, Y. A., \& Folarin, S. F. (2014). Managing ethnic and cultural diversity for national integration in Nigeria. Developing Country Studies, 4(6), 70-76. http://eprints.covenantuniversity.edu.ng/3242/1/Dr\%20Edewor.pdf

Ennaji, M. (2005). Multilingualism, cultural identity, and education in Morocco. Springer Science \& Business Media.

Freire, J. A. (2020). Promoting Sociopolitical Consciousness and Bicultural Goals of Dual Language Education: The Transformational Dual Language Educational Framework. Journal of Language, Identity \& Education, 19(1), 56-71.

Fuller, J. M. (2007). Language choice as a means of shaping identity. Journal of Linguistic Anthropology, 17(1), 105-129. http://www.jstor.org/stable/43104134

Gelman, S. A., \& Roberts, S. O. (2017). How language shapes the cultural inheritance of categories. Proceedings of the National Academy of Sciences, 114(30), 7900-7907.

Giri, R. A. (2010). Cultural anarchism: The consequences of privileging languages in Nepal. 
Journal of Multilingual and Multicultural Development, 31(1), 87-100.

https://doi.org/10.1080/01434630903398103

Giri, R. A. (2011). Languages and language politics: How invisible language politics produces visible results in Nepal. Language Problems and Language Planning, 35(3), 197-221. https://doi.org/https://doi.org/10.1075/lplp.35.3.01gir

Gurung, S. (2019, September 6). The Gurung language once had no written script. Now it has five. The Kathmandu Post, 1. https://kathmandupost.com/artculture/2019/09/06/the-gurung-language-once-had-no-written-script-now-it-has-five

Hall, S. (1997). Representation: Cultural representations and signifying practices (Vol. 2).

Sage. Katuwal, J. (2018, May 9). Khas language on the verge of extinction, experts warn. The Kathmandu Post. https://kathmandupost.com/national/2018/05/09/khas-language-onthe-verge-of-extinction-experts-warn

Kennedy, J. (2019). Relational cultural identity and Pacific language education.

International Education Journal: Comparative Perspectives, 18(2), 26-39.

https://openjournals.library.sydney.edu.au/index.php/IEJ

Kinzler, K. D., Corriveau, K. H., \& Harris, P. L. (2011). Children 's selective trust in native accented speakers. Developmental science, 14(1), 106-111.

https://doi.org/10.1111/j.1467-7687.2010.00965.x

Li, G. (2013). Promoting teachers of culturally and linguistically diverse (CLD) students as change agents: A cultural approach to professional learning. Theory Into Practice, 52(2), 136-143. https://doi.org/10.1080/00405841.2013.770331

Maine, F., Cook, V., \& Lähdesmäki, T. (2019). Reconceptualizing cultural literacy as a dialogic practice. London Review of Education, 17(3), 383-392. https://doi.org/10.18546/LRE.17.3.12

Miller, R. L., \&-Collette, T. (2019). Multicultural identity development: Theory and research. Cross Cultural Psychology: Contemporary Themes and Perspectives, 614-631.

Phyak, P. (2013). Language ideologies and local languages as the medium-of-instruction policy: A critical ethnography of a multilingual school in Nepal. Current Issues in Language Planning, 14(1), 127-143. https://doi.org/10.1080/14664208.2013.775557

Pinto, S., \& Araújo e Sá, M. H. (2020). Researching across languages and cultures: a study with doctoral students and supervisors at a Portuguese University. European Journal of Higher Education, 1-18.

Silwal, M. (2011). Maternal health care practices among indigenous people of Nepal: A case study of the Raute community (Publication Number 09) University of Troms $\varnothing$ ]. https://hdl.handle.net/10037/3448

Vygotsky, L. S. (1980). Mind in society: The development of higher psychological processes. Harvard University Press. 